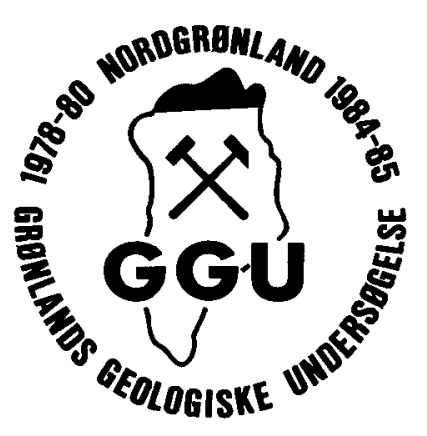

\title{
The Navarana Fjord Member (new) - an Upper Llandovery platform derived carbonate conglomerate
}

\author{
Finn Surlyk and J. R. Ineson
}

\begin{abstract}
A new lithostratigraphical unit, the Navarana Fjord Member of latest Llandovery age, is formally erected in this paper. It consists of an up to $80 \mathrm{~m}$ thick sequence of amalgamated carbonate conglomerate beds. The member is presently known from the east and west coast of Navarana Fjord, central North Greenland. It rests or Silurian carbonate platform to the south. To the north of the platform margin scarp it rests on and interfingers with turbidites of the Merqujôq Formation. The member is included in the Merqujôq Formation and forms an important marker reflecting the final foundering of the outer carbonate platform.
\end{abstract}

F. S., Grønlands Geologiske Undersøgelse, Øster Voldgade 10, DK-1350 København K, Denmark.

J. R. I., British Antarctic Survey, High Cross, Madingley Road, Cambridge CB3 OET, U.K. Present address: University of London, Goldsmiths' College, New Cross, London SE146NW, U.K.

A detailed study of the stratigraphy of the Silurian Peary Land Group was undertaken by Hurst \& Surlyk (1982). Later field work has resulted in refinements of some parts of the stratigraphical scheme and in the introduction of several new units by Larsen \& Escher $(1985,1987)$. In the present paper we erect a new unit, the Navarana Fjord Member, a carbonate conglomerate which marks the final drowning of the outer carbonate platform in Late Llandovery time. Additional sedimentological information is given by Surlyk \& Ineson (1987).

\section{Navarana Fjord Member}

(new member of the Merqujôq Formation)

Name. After Navarana Fjord between Freuchen Land and Lauge Koch Land.

Type section. West coast of Navarana Fjord (fig. 1).

Thickness. Up to about $80 \mathrm{~m}$ at the Navarana Fjord scarp (fig. 2; see also figs $8 \& 9$ in Surlyk \& Ineson, 1987). 


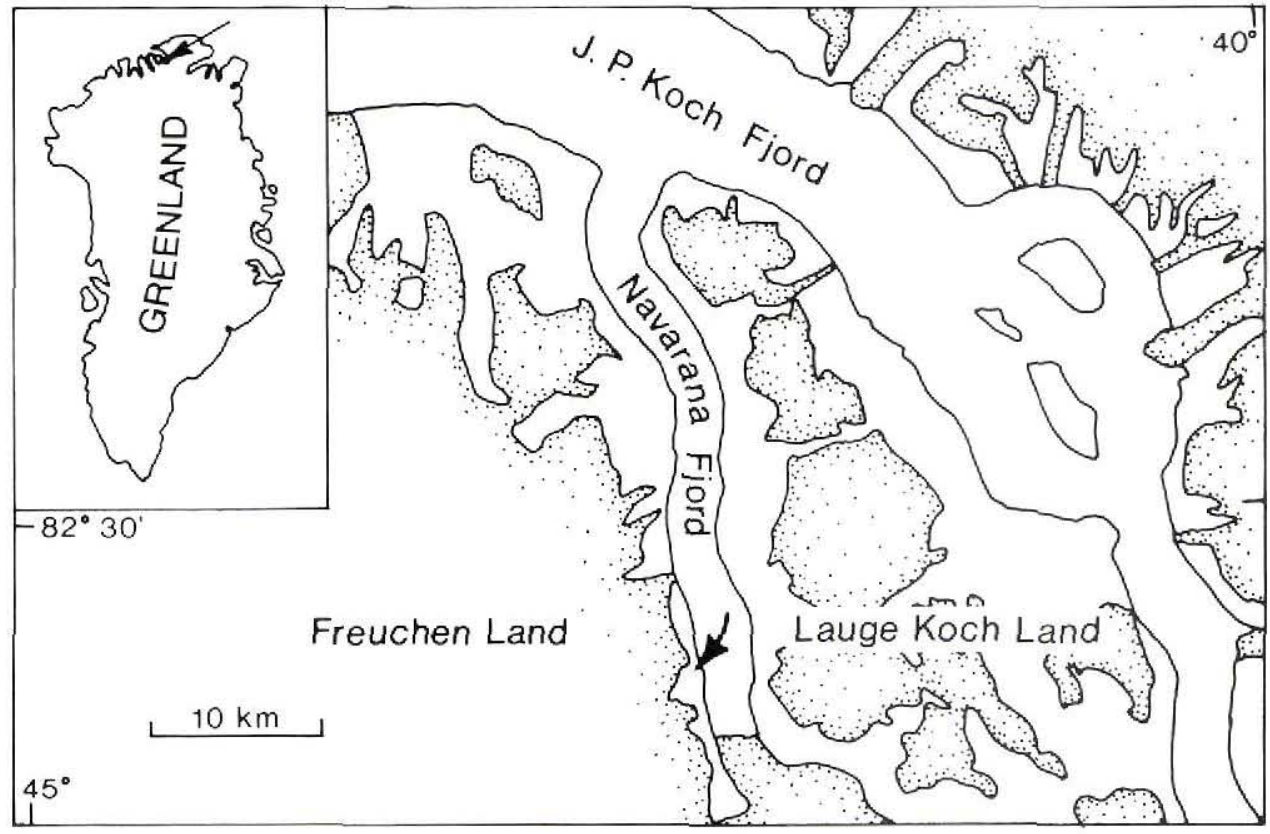

Fig. 1. Sketch map showing the position of the type locality of the Navarana Fjord Member, Merqujôq Formation.

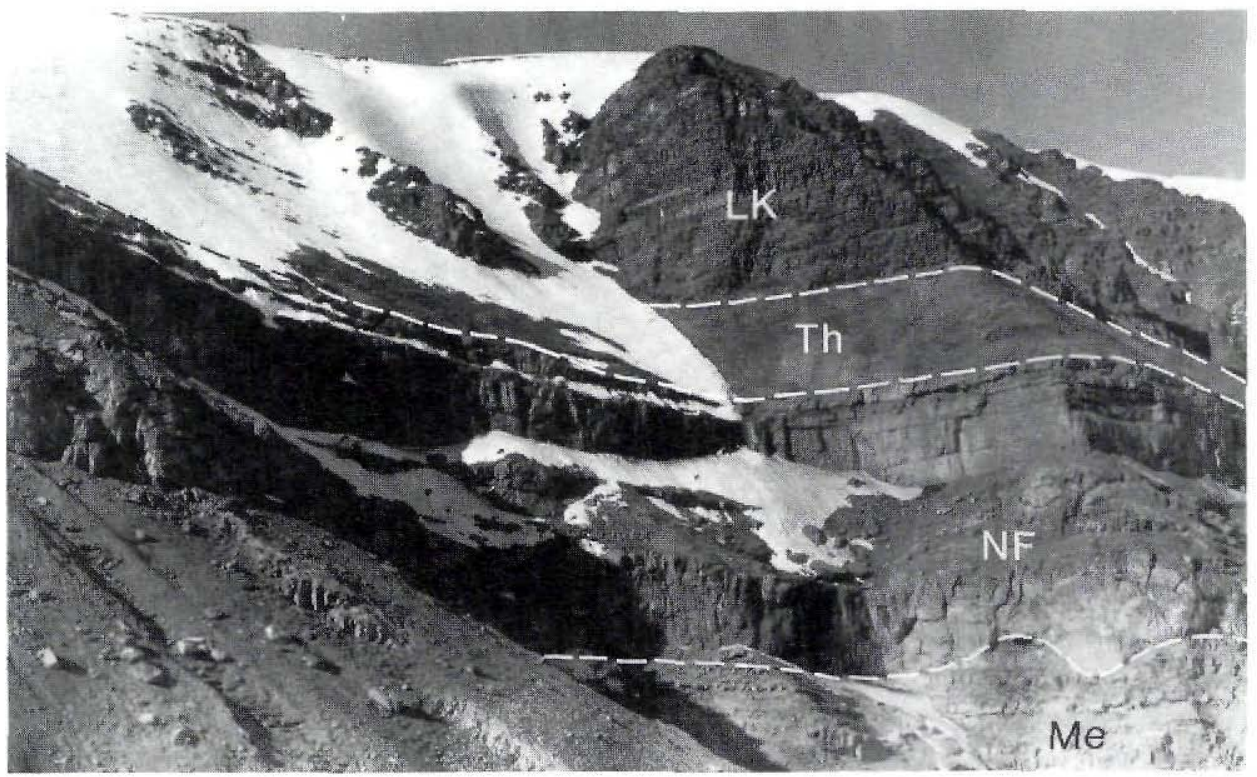

Fig. 2. Type locality of the Navarana Fjord Member (NF) on the west coast of Navarana Fjord, showing the amalgamated nature of the carbonate conglomerate beds. The lowest massive bed is shown on fig. 3 . $\mathrm{Me}=$ turbidites of the Merqujôq Formation; $\mathrm{Th}=$ shales of the Thors Fjord Member; $\mathrm{LK}=$ turbidites of the Lauge Koch Land Formation. 


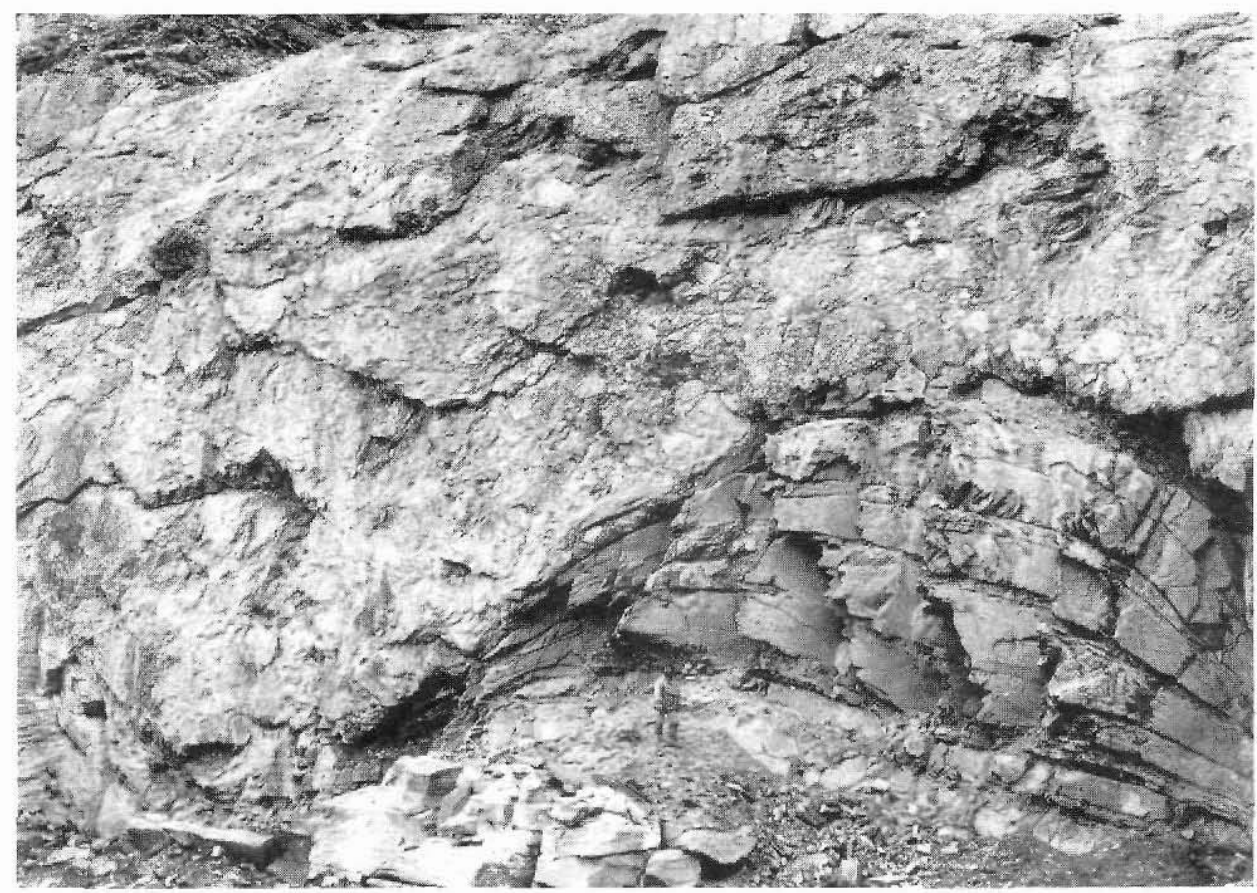

Fig. 3. Gigantic load structures of the Navarana Fjord Member conglomerates into the top of the Merqujôq Formation turbidites. Note figure for scale. Same locality as fig. 8 in Surlyk \& Ineson (1987).

Lithology. Thick amalgamated conglomerate unit composed of carbonate blocks derived from the southern Silurian platform (figs 2, 3, 4; see also figs 8, 9, 10, 12 in Surlyk \& Ineson, 1987). The thicker beds are commonly loaded into turbidites of the Merqujô Formation (fig. 3); thinner beds show pronounced pinching and swelling and terminal wedging. Some thick beds show crude low-angle cross-stratification probably reflecting northwards overriding and deposition of individual debris flows. The conglomerates have been subject to intense pressure solution resulting in matrix dissolution and welding of clasts. Where present the matrix consists of carbonate mud, sand and fine pebbles. The clasts are mainly in the coarse pebble to fine cobble grade (fig. 4), but boulder beds also occur (fig. 3), and some beds contain blocks up to $50 \mathrm{~m}$ in largest dimension.

Boundaries. The lower boundary is taken at the base of the thick conglomerate onlapping the platform edge (fig. 2). The lower part of the member interfingers with the highest sandstone turbidites of the Merqujôq Formation. The upper boundary is taken at the top of the last of the thick conglomerates in this location, where it interfingers with the basal part of the overlying Thors Fjord Member (fig. 2).

Distribution. The member is presently known from the east and west coast of Navarana Fjord in the immediately adjacent areas of Lauge Koch Land and Freuchen Land. Carbonate conglomerates seem to occur in a similar stratigraphic position on the north coast of Hall Land (P.-H. Larsen, personal communication, 1986). 


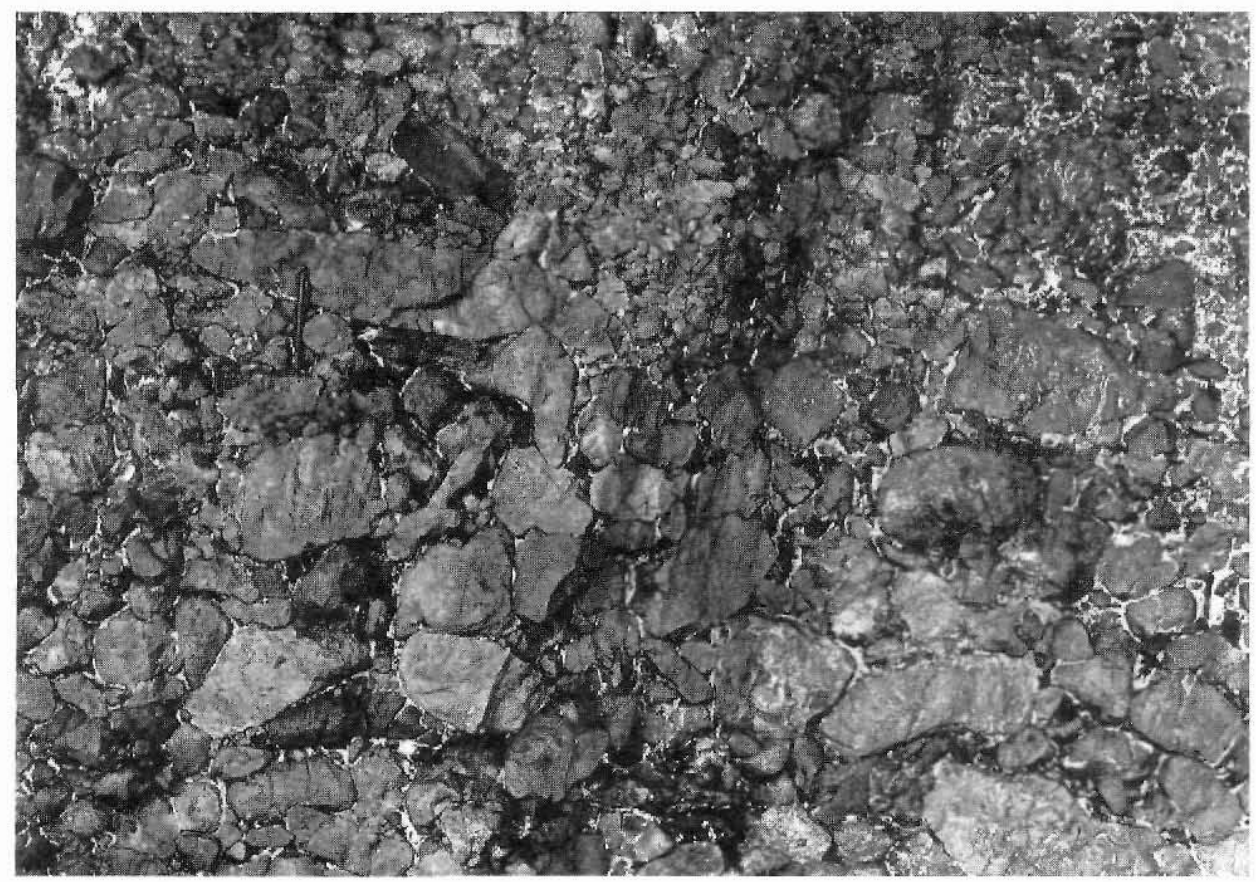

Fig. 4. Detail of one of the finer grained parts of the conglomerate shown in fig. 3. Note the pressurewelded contacts of the clasts. Pencil for scale in upper left corner.

Geological age. In the type locality the graptolites Monograptus spiralis spiralis and Monograptus priodon have been found in the Merqujôq Formation turbidites a few tens of metres below the Navarana Fjord Member. They indicate the Upper Llandovery spiralis Zone. A big slab of black shale of the Thors Fjord Member in the upper part of the Navarana Fjord Member contained the graptolites Monoclimacis vomerinus vomerinus, Monoclimacis linnarsoni?, Cyrtograptus aff. lapworthi and Plematograptus sp. indicating the uppermost Llandovery sakmaricus-laqueus Zone. The same zone is indicated for the overlying Thors Fjord Member by the presence of Cyrtograptus aff. lapworthi. The Navarana Fjord Member is thus of Late Llandovery age and probably belongs mainly to the Late Llandovery spiralis Zone while the top part reaches into the sakmaricus-laqueus Zone.

Acknowledgements. We thank M. Bjerreskov for identification and biostratigraphic assignment of the graptolite faunas. B. Larsen, J. Lautrup and B. Sikker Hansen provided technical assistance in the preparation of the manuscript.

\section{References}

Hurst, J. M. \& Surlyk, F. 1982: Stratigraphy of the Silurian turbidite sequence of North Greenland. Bull. Gronlands geol. Unders. 145, $121 \mathrm{pp}$.

Larsen, P.-H. \& Escher, J. C. 1985: The Silurian turbidite sequence of the Peary Land Group between Newman Bugt and Victoria Fjord, western North Greenland. Rapp. Grønlands geol. Unders. 126, $47-67$. 
Larsen, P.-H. \& Escher, J. C. 1987: Additions to the lithostratigraphy of the Peary Land Group in western and central North Greenland. Rapp. Grønlands geol. Unders. 133, 65-80.

Surlyk, F. \& Ineson, J. R. 1987: Aspects of Franklinian shelf, slope and trough evolution and stratigraphy in North Greenland. Rapp. Grønlands geol. Unders. 133, 41-58. 